\title{
Using Partial Least Squares Structural Equation Modeling to Measure the Moderating Effect of Gender: An Empirical Study
}

\author{
Vera Gelashvili (D), Juan-Gabriel Martínez-Navalón and José Ramón Saura *(D) \\ Department of Business Economics, Faculty of Social Sciences and Law, Rey Juan Carlos University, Móstoles, \\ 28933 Madrid, Spain; vera.gelashvili@urjc.es (V.G.); juangabriel.martinez@urjc.es (J.-G.M.-N.) \\ * Correspondence: joseramon.saura@urjc.es
}

check for updates

Citation: Gelashvili, V;

Martínez-Navalón, J.-G.; Saura, J.R. Using Partial Least Squares Structural Equation Modeling to Measure the Moderating Effect of Gender: An Empirical Study. Mathematics 2021, 9, 3150. https://doi.org/10.3390/ math9243150

Received: 16 October 2021

Accepted: 4 December 2021

Published: 7 December 2021

Publisher's Note: MDPI stays neutral with regard to jurisdictional claims in published maps and institutional affiliations.

Copyright: (c) 2021 by the authors. Licensee MDPI, Basel, Switzerland. This article is an open access article distributed under the terms and conditions of the Creative Commons Attribution (CC BY) license (https:// creativecommons.org/licenses/by/ $4.0 /)$.

\begin{abstract}
Over recent decades, much has been written about sustainable development and its main dimensions (environmental, social, and economic). However, to date, there is a lack of academic literature on the relationship between these dimensions of sustainability, as well as whether sustainability is moderated by an individual's gender. To fill this gap in the literature, the aim of this study is two-fold: first, we want to empirically analyze whether there is a relationship between these dimensions and, if so, whether this relationship is positive; secondly, we aim to evaluate whether gender influences the link between these dimensions of sustainability. To this end, a sample of 411 responses was analyzed using the Using Partial Least Squares Structural Equation Modeling (PLS-SEM) methodology. The results revealed that there is a positive relationship between the three dimensions of sustainability; however, the effect of gender was observed only in the case of the relationship between social and environmental sustainability. The paper concludes with a discussion of the results and an outline of their theoretical and practical implications for industry.
\end{abstract}

Keywords: economic sustainability; gender; PLS-SEM

\section{Introduction}

In the last several decades, an increasing number of studies or actions at both national and international levels have sought to promote sustainable development. Sustainable development is primarily understood as advances that improve people's quality of life, in relation to the capacity of natural resources. Accordingly, sustainability is considered as the basis to remove poverty and hunger, promote health and well-being for everyone, as well as to ensure quality education, gender equality, decent work, economic growth, and affordable and clean energy for all. All these sustainable development objectives can be broadly divided into the following three dimensions (or pillars): environmental sustainability, social sustainability, and economic sustainability [1,2]. Therefore, when using the concept of sustainability, it is necessary to take into account the context-be it social, economic or environmental-where this term is used [3].

In previous research, the three dimensions of sustainable development have been studied separately or together; however, environmental sustainability has been of particular interest in most studies [4,5]. Some authors have highlighted the need for more studies or actions to consider social and economic sustainability that have not been as strongly emphasized as environmental sustainability [6]. According to Purvis et al. [5], the three dimensions of sustainability are intrinsically interrelated, which makes it difficult to separate them. This suggests that whenever a dimension of sustainability is implemented, it also contributes to the other two dimensions. Accordingly, the relationship among all dimensions of sustainability is positive. However, to the best of our knowledge, none of the previous studies have empirically analyzed these relationships on a sampling basis [7].

The main objective of the present study is to conduct an empirical analysis of the relationship between these three dimensions of sustainability and to explore whether this relationship is moderated by gender. The gender variable is introduced into the model 
because several academic studies have reported that gender can positively influence the implementation or creation of sustainable development $[8,9]$.

To achieve the stated objective, a partial least squares structural equation modeling (PLS-SEM) methodology was used. The results revealed a positive relationship among the three dimensions of sustainability; however, gender was found to moderate only the relationship between social sustainability and environmental sustainability; therefore, gender was not a significant variable in the relationship between economic and environmental sustainability and economic and social sustainability.

The remainder of this manuscript is organized as follows: Section 2 reviews previous literature on different dimensions of sustainability and gender. Section 3 presents the hypotheses that are tested in this study. Section 4 presents information on the data collection and analysis. Section 5 reports the results. Conclusions are drawn in Section 6.

\section{Theoretical Framework}

The concept of sustainability was first defined in the United Nations General Assembly Report of the World Commission on Environment and Development. In this report, sustainability was defined as "development that meets the needs of the present without compromising the ability of future generations to meet their own needs" [10] (p. 39). The document analyzed three different types of sustainability: environmental, economic, and social. However, despite the popularity of the concept, the definition provided by Brundtland et al. [10], and the objectives of sustainable development in general [11], have been criticized on many occasions. Yet, these criticisms have not prevented integration of sustainability into the political agendas and strategies of large organizations [12]; it has to be acknowledged that sustainability is an organizational issue. Nowadays, corporate sustainability is an issue that is gaining more and more interest as companies realize its value and benefits [13-15]. One of the benefits that a focus on sustainability brings to business is its positive relationship with sustainable performance. According to Herbohn [13], a company's sustainability performance is strongly linked to its disclosure. This means that companies should pay close attention to the correct disclosure and implementation of sustainability in the company as its results can affect the organisation. Not only for this reason, but also because of its importance for society in general, companies and governments should promote the correct implementation of sustainability in private or public companies. Many government initiatives and public actions focus on integrating sustainability into the university curriculum. According to Adams [16], the integration of sustainability in universities as an operational, strategic and outreach principle, has had a positive impact. Furthermore, it is considered mandatory and ethical to study and promote sustainability in universities $[17,18]$ as they are organisations that train the future generations who must carry out sustainable actions in their work or daily life.

The major three dimensions of sustainable development are analyzed below.

\subsection{Social Sustainability}

According to Basiago [1], social sustainability is understood as a system of social organization that reduces poverty. Many authors across the globe have studied the importance of social sustainability for the achievement of a more balanced world for everyone [6,19-21]. According to Dempsey et al. [20], social sustainability is a wide-ranging, multi-dimensional concept whose main objective is to achieve the social goals of sustainable development.

Therefore, social sustainability is a crucial component of global sustainability. Social sustainability is a positive condition that improves life within communities that is marked by a strong sense of social cohesion and equal access to services such as health, education, transport, housing and leisure, among many others [22].

Despite the recent focus of European policy on sustainable societies and social cohesion, at present, there is a lack of theoretical and empirical studies regarding social sustainability [6]. At the same time, many previous studies have investigated components 
of social sustainability, such as social capital, social cohesion, as well as social inclusion or exclusion [20,23-25].

\subsection{Economic Sustainability}

Another dimension of sustainability is the economic dimension. According to Cadil et al. [26], economic sustainability can be described as the process of allocating and preserving scarce resources while ensuring positive social and environmental outcomes. This presupposes using renewable assets to avoid shortages of essential resources in the future. Consequently, companies that can effectively manage their environment and social justice will also become more economically sustainable $[27,28]$.

According to Janoušková et al.'s [4] perspective on the present-day economy, businesses and governments need to continuously use anticipation and precaution to promote sustainability. Until recent decades, there had been no shortage of essential commodities and assets [3]. However, current consumption levels must be considered without compromising future needs [1].

In this context, companies should be able to manage their assets in a responsible way to both generate profit from their activities and, at the same time, promote responsible consumption through a financial system based on green businesses. This strategy can, in some cases, induce companies to gradually or drastically transform, or encourage the creation of new businesses.

\subsection{Environmental Sustainability}

Environmental sustainability is the most extensively studied dimension of sustainability. The definition of environmental sustainability focuses on natural biological processes, as well as on the continued productivity and functioning of ecosystems over time [5]. Goodland [3] pointed out that, originally, the term "environmentally responsible" was used to describe the term "development". Subsequently, the term "environmentally sustainable development" came into widespread use and, finally, the concept of "environmental sustainability" was developed. Environmental sustainability seeks to improve human well-being by protecting and conserving the sources of raw materials used for human needs in order to prevent damage to humans or the environment [4,29].

Among the many and varied issues investigated in recent studies on environmental sustainability are food waste, the green economy, recycling, climate change, and the promotion of environmental sustainability in developing countries [30-33]. All these aspects of environmental sustainability are essential to create a better world, to maintain the status quo, and to avoid environmental disasters. However, in their comprehensive literature review, Howes et al. [34] demonstrated that, due to economic, political and communication factors, environmental commitments are not fully respected.

\subsection{Gender and Sustainability}

The gender variable has been extensively studied in the academic literature [35-38]. Available studies have underscored the importance of gender. For instance, Powell and Ansic [39] pointed out that men and women adopt different strategies with regard to financial decisions. Specifically, the authors found that, in business settings, women are less risk-seeking than men, suggesting that, whenever it comes to making a risk-based decision, women prefer not to take risks. These conclusions were substantiated in several other studies (e.g., Brooks et al. [40]; Fisher and Yao, [36]) concluded that women's less risky behavior and decision making may be related to their lack of experience in the financial market.

Marketing is another field where much research has been undertaken on the importance of gender [41]. For instance, a recent empirical study on consumer's online [37] decision-making found that customers' purchase intentions strongly correlated with gender [42]. In the case of online tourism shopping, gender was found to be one of the key factors affecting intention to repurchase and customers' trust [43]. Specifically, when pur- 
chasing decisions were made by men, trust and repurchase intention were more strongly related to cost-effectiveness in comparison with women.

Other recent studies have focused on the relationship between gender and sustainability $[7,8,44]$. For instance, Meinzen-Dick et al. [7] found a positive relationship between the presence of women on boards of directors and economic growth which, in turn, is related to economic sustainability. At the same time, male directors were found to be more committed to environmental sustainability. In contrast to these findings, another study on corporate social responsibility for sustainability found that the role of women in promoting environmental sustainability was stronger than that of men [9]. Based on the evidence discussed above, it can be concluded that sustainable development, regardless of the dimension of sustainability, could be influenced by gender.

\section{Hypotheses and Research Model Development}

This research paper was framed in a context of crisis initiated by the COVID-19 pandemic. While the dimensions of this crisis and the number of affected areas are innumerable, the present study focuses mainly on sustainability and its objectives. As discussed in the literature review, the concept of sustainability has evolved during recent decades and has become a popular term used in a range of contexts. Considering these different contexts, we can distinguish among environmental sustainability, economic sustainability, and social sustainability $[45,46]$.

Our review of the literature on the significant differences between men and women in the sustainability context $[8,47]$ revealed that there is not a large amount of academic literature on this topic [7]. Among relevant past studies, Olsson and Gericke [8] sought to find out whether there were significant differences between girls and boys (from a nationwide Swedish sample) in perceiving, analyzing, and raising awareness of sustainability. The results of this study showed that girls were in general more conscious about sustainability than boys. However, Glass et al. [48] did not find evidence that female CEOs would implement more environmentally sustainable practices. Therefore, the results of previous studies on the role of gender in sustainability are inconsistent.

In the present study, we seek to analyze the relationship between the three different types of sustainability. Specifically, our aim is to establish whether economic sustainability has a positive impact on environmental sustainability, and whether social sustainability has a positive and direct impact on environmental sustainability. In several previous studies on sustainability, it has been argued that it is not possible to achieve environmental, social, or economic sustainability separately [49], as all three dimensions of sustainability are intrinsically interrelated and influence each other.

The main objective of this paper is to assess whether there are significant gender differences when analyzing different models of sustainability; our secondary goal is to establish whether there are positive and direct relationships between different types of sustainability. To this end, we jointly considered the variables of gender, environmental sustainability, social sustainability, and economic sustainability.

Despite the lack of previous empirical studies on the direct influence of economic sustainability on environmental sustainability, several previous studies have explored the relationship between the economic and environmental performance of companies. For instance, Schaltegger and Wagner [50] showed that there was a direct link between a firm's economic and environmental performance, and that this link was positive. Accordingly, an increase in economic performance implied improvement of environmental performance. Of note, however, is that the terms "economic performance" and "environmental performance" are quite broad and might not (especially, in the case of economic performance) include sustainability.

It is important to analyze gender differences when studying the relationship between variables. The existence of differences in these relationships can be generated from childhood [51].

Based on the evidence briefly reviewed above, the following hypotheses were formulated: 
Hypothesis 1a (H1a). Economic sustainability has a direct and positive impact on environmental sustainability.

Hypothesis $\mathbf{1 b}(\mathbf{H 1} \mathbf{b})$. There are significant differences between men and women in the influence of economic sustainability on environmental sustainability.

Economic and social sustainability have always been linked, as the concept of economic sustainability refers to performing economically profitable practices without neglecting social equity [26]. For instance, job creation and maintenance can contribute to both social and economic sustainability [52]. From the social sustainability perspective, unemployed people or people who experience difficulties in finding a job (e.g., due to disability) decrease social equality. In the case of economic sustainability, it can be argued that the more employment there is, the more likely it is to generate profit.

In addition, it is necessary to take into account the social economy developed to create alternative economic and social opportunities for people excluded from social life and the labor market [53]. We can predict that social value will be related to the economic value created by companies. This implies that social sustainability has an impact on the generation or creation of economic sustainability.

Studies on gender differences are common in young people and students. Such studies also consider the effects of age differences. Differences often first arise in childhood [54].

Based on the considerations presented above, the following hypotheses were formulated:

Hypothesis 2a (H2a). Economic sustainability has a direct and positive impact on social sustainability.

Hypothesis $\mathbf{2 b}(\mathbf{H} \mathbf{2} \mathbf{b})$. There are significant differences between men and women in the influence of economic sustainability on social sustainability.

As mentioned earlier, environmental sustainability has been one of the most studied pillars/dimensions of sustainability $[5,34,52]$. In contrast, social sustainability has been the least studied dimension [55]. Previous studies on the direct relationship between social and environmental sustainability are scarce, even though, as mentioned above, several previous studies have analyzed these two dimensions of sustainability either jointly or separately.

As argued by Purvis et al. [5], there are three possible types of interactions among the dimensions of sustainability: (1) The three dimensions of sustainability contribute to each other (as in three intersecting circles); (2) Social and economic sustainability are analyzed as a part of environmental sustainability, i.e., they are understood as parts of environmental sustainability; (3) Each of the dimensions of sustainability is understood separately, without any interaction between them. With regard to options 1 and 2 above, it can be said that there is a link between social and environmental sustainability. Murphy [55] pointed out the need for further research on the relationship between these two dimensions and concluded that the social dimension can be understood as a holistic concept embracing different dimensions, such as the environmental dimension.

Ravindran, Yeow Kuan and Lian [56] raise the importance of gender differences. The relationships between variables should also be studied in terms of the effects that arise when analyzing by gender and age. This relates to the fact that both age and gender often play, and have played, a vital role in acceptance and post-adoption studies with respect to a range of variables.

Accordingly, in the present study, we formulated and test the following hypotheses:

Hypothesis 3a (H3a). Social sustainability has a direct and positive impact on environmental sustainability.

Hypothesis $\mathbf{3 b} \mathbf{( H 3 b ) . ~ T h e r e ~ a r e ~ s i g n i f i c a n t ~ d i f f e r e n c e s ~ b e t w e e n ~ m e n ~ a n d ~ w o m e n ~ i n ~ t h e ~ i n f l u e n c e ~}$ of social sustainability on environmental sustainability. 
The research model based on the hypotheses formulated in this section is shown in Figure 1.

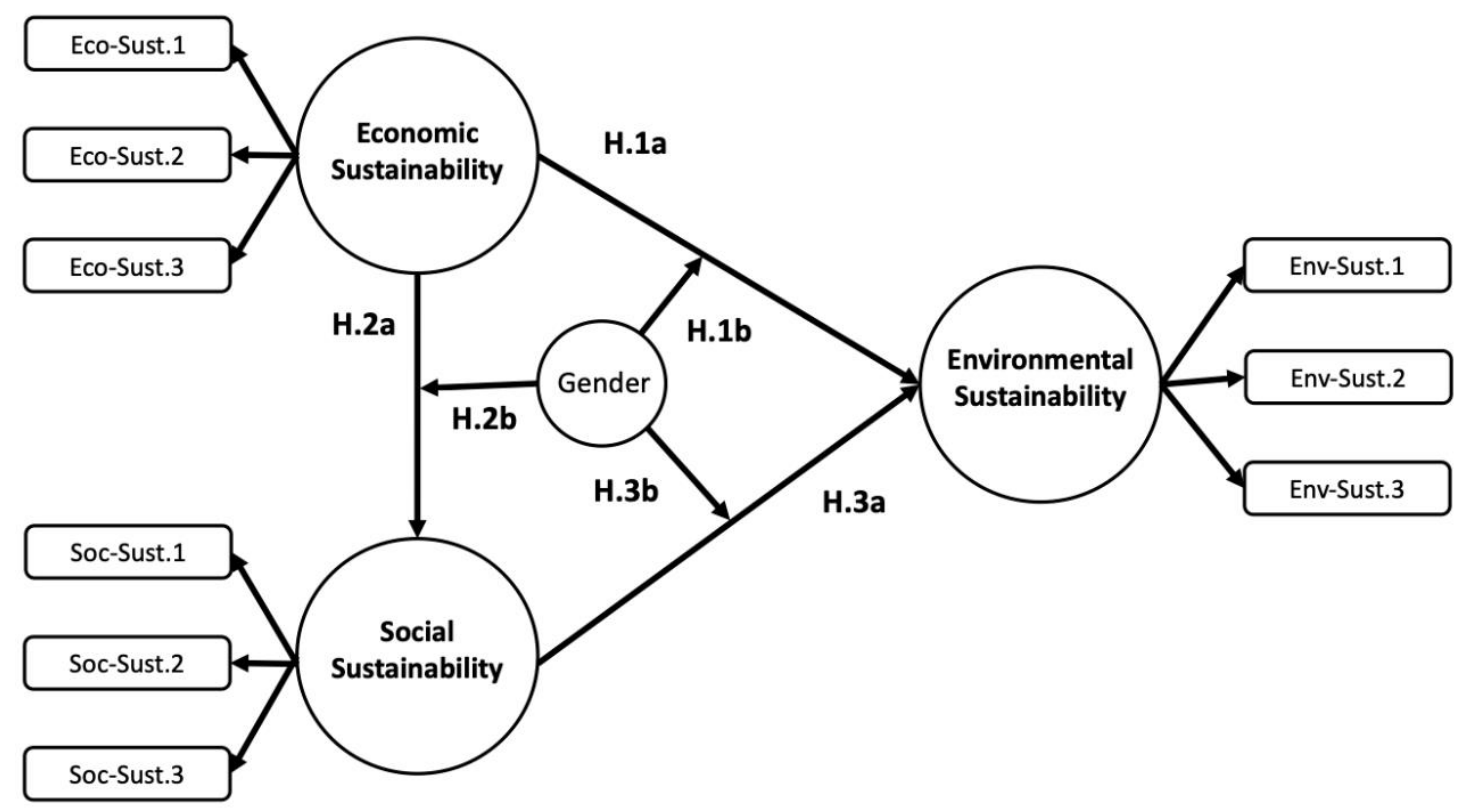

Figure 1. Proposed Research Model.

This section is divided by subheadings. It aims to provide a concise and precise description of the experimental results, their interpretation, as well as the conclusions that can be drawn.

\section{Data Analysis}

\subsection{Data Collection}

For data collection, a questionnaire was developed based on a literature review of relevant previous studies. The questionnaire was disseminated online for self-completion.

The questionnaire was distributed via email and through social networks (Facebook, LinkedIn and WhatsApp) targeting university students studying in Spain. We chose the sample of students because they represent the future generation that must be involved in taking sustainable actions. Furthermore, the Agenda 2030 for Sustainable Development adopted by the United Nations [57] shone a spotlight on universities to promote and support the sustainable development of society. This is because universities train future generations who must respect, support and promote sustainable actions [17,18]; the participation of students in the sustainable development of a society is crucial.

Both methods of questionnaire dissemination were used because of COVID-19-related restrictions that were in force at the time of data collection. A convenience sampling approach was used because it was not possible to send the questionnaire to all university students who were studying in public universities at the time.

In order to ensure that the survey was limited to the opinions of university students, one of the first questions in the questionnaire was "Do you study at a Spanish university?" Our aim was to measure the variables set out in the model from the perspective of current university students. This allowed us to collect the opinions of the most critical and active stakeholder group, that of university students, regarding economic, social, and environmental sustainability.

The questionnaire used in the study comprised a total of 15 questions divided into two blocks. The first block contained the questions concerning the respondents' demographic profiles. The second block contained items addressing the concept of sustainability. The items were rated on a 6-point Likert scale, from $0=$ "strongly disagree" to $5=$ "strongly 
agree". This measurement scale is the most commonly used scale for collecting survey data, as well as the most commonly used type of scale in the field of social sciences [58].

\subsection{Data Analysis}

Once the sample was obtained and the database was generated, validation of the scale of measurement proposed for the analysis of the database was performed. To this end, we used structural equation modeling based on PLS variances [59].

PLS facilitates the analysis and estimation of the structural measurement model proposed taking into account the dependent variables of the model. This technique makes it possible to quantify the size of both direct and indirect effects between variables [60].

The PLS-SEM technique has been widely used in the field of social sciences, particularly in previous studies analyzing datasets from social networks. Furthermore, the PLS-SEM technique has also been widely used to investigate relationships that have not yet been studied [61,62].

This research paper was framed in the context of crisis initiated by the COVID19 pandemic. While the dimensions of this crisis and the number of affected areas are innumerable, the present study focuses mainly on sustainability and its objectives. As discussed in the literature review, the concept of sustainability has evolved during recent decades and has become a popular term used in a range of contexts. Considering these different contexts, we can distinguish among environmental sustainability, economic sustainability, and social sustainability $[45,46]$.

\section{Analysis of Results}

\subsection{Descriptive Analysis}

A total of 430 respondents filled in the questionnaire, and 411 responses were validated for inclusion in the dataset. Before running the analyses with the Smart-Pls 3.0 software to test the hypotheses, to obtain a better insight into the survey data and respondents' profiles, we evaluated the characteristics of the sample. The results of the descriptive analysis are summarized in Table 1.

Table 1. Sample Characteristics $(n=411)$.

\begin{tabular}{|c|c|c|c|}
\hline Classification Variable & Variable & Frequency & Percentage \\
\hline \multirow[b]{2}{*}{ Gender } & Male & 133 & $32.36 \%$ \\
\hline & Female & 278 & $67.63 \%$ \\
\hline \multirow{5}{*}{ Age } & $<18$ & 7 & $2 \%$ \\
\hline & $18-24$ & 351 & $85 \%$ \\
\hline & $24-26$ & 29 & $7 \%$ \\
\hline & $26-40$ & 13 & $3 \%$ \\
\hline & $>40$ & 11 & $3 \%$ \\
\hline
\end{tabular}

Source: The authors.

Table 1 shows the composition of the study sample. With regard to gender, $67.63 \%$ of the respondents were female, while $32.36 \%$ were male. Most respondents $(85 \%)$ were aged 18-24 years old. The results of this analysis of the sample reflect the Spanish university population, where the percentage of female students is higher than that of male students and where most students are aged between 18 and 24 years old [63].

Before starting the measurement model study, an analysis of the mean of the variables analyzed (economic sustainability, social sustainability and environmental sustainability) was carried out, differentiating the mean of the variables and dimensions according to the gender of the individuals. This process was carried out to assess if it was appropriate to perform an analysis that considered significant differences between the relationships according to the gender of the participants, as shown in Table 2. 
Table 2. Means of the variables according to gender.

\begin{tabular}{ccccc}
\hline Classification Variable & Items & Male & Female & Mean \\
\hline \multirow{3}{*}{ Economic Sustainability } & Eco-Sust 1 & 3.62 & 3.12 & 3.37 \\
& Eco-Sust 2 & 2.80 & 3.17 & 2.99 \\
& Eco-Sust 3 & 3.85 & 3.20 & 3.53 \\
\hline \multirow{2}{*}{ Social } & Media & 3.43 & 3.16 & 3.30 \\
\hline Sustainability & Soc-Sust 1 & 2.81 & 3.52 & 3.17 \\
& Sos-Sust 2 & 3.12 & 3.42 & 3.27 \\
& Sos-Sust 3 & 3.16 & 3.13 & 3.15 \\
\hline \multirow{2}{*}{ Environmental } & Media & 3.03 & 3.36 & 3.20 \\
Sustainability & Env-Sust 1 & 3.33 & 3.36 & 3.35 \\
& Env-Sust 2 & 3.60 & 3.11 & 3.36 \\
& Env-Sust 3 & 3.47 & 2.72 & 3.10 \\
\hline & Mean & 3.47 & 3.06 & 3.27 \\
\hline
\end{tabular}

Source: The authors.

Once the averages for the different variables were calculated, the data were found to be heterogeneous with respect to gender, i.e., there were differences in the perception of sustainability depending on the gender of the respondent. In general, it was found that men rated the universities where they studied more highly than women with respect to economic and environmental sustainability. In contrast, in the case of social sustainability, female participants rated their university more highly than the male participants.

These data show that there were differences between the means of the variables if we classify according to gender. This indicates that a moderating analysis of the relationships in the model by gender would be desirable because there are indications of possible significant differences.

\subsection{Measurement Model}

Once the characteristics of the sample were established, the analysis of the proposed measurement model was carried out to test the formulated hypotheses. First, a reliability analysis of the measurement scale was performed. Second, we proceeded with an analysis of the relationships predicted by the model and validation of whether there was a relationship between the variables. Finally, a multi-group analysis was carried out to determine whether there was a moderating effect of gender on the different relationships among the dimensions of sustainability.

In the first stage, and considering that all indicators of the study were reflective according to [60], analyses of individual item reliability, construct reliability, convergent validity, and discriminant validity were performed $[62,64]$. The results of these analyses are summarized in Tables 3 and 4. 
Table 3. Measurement Items.

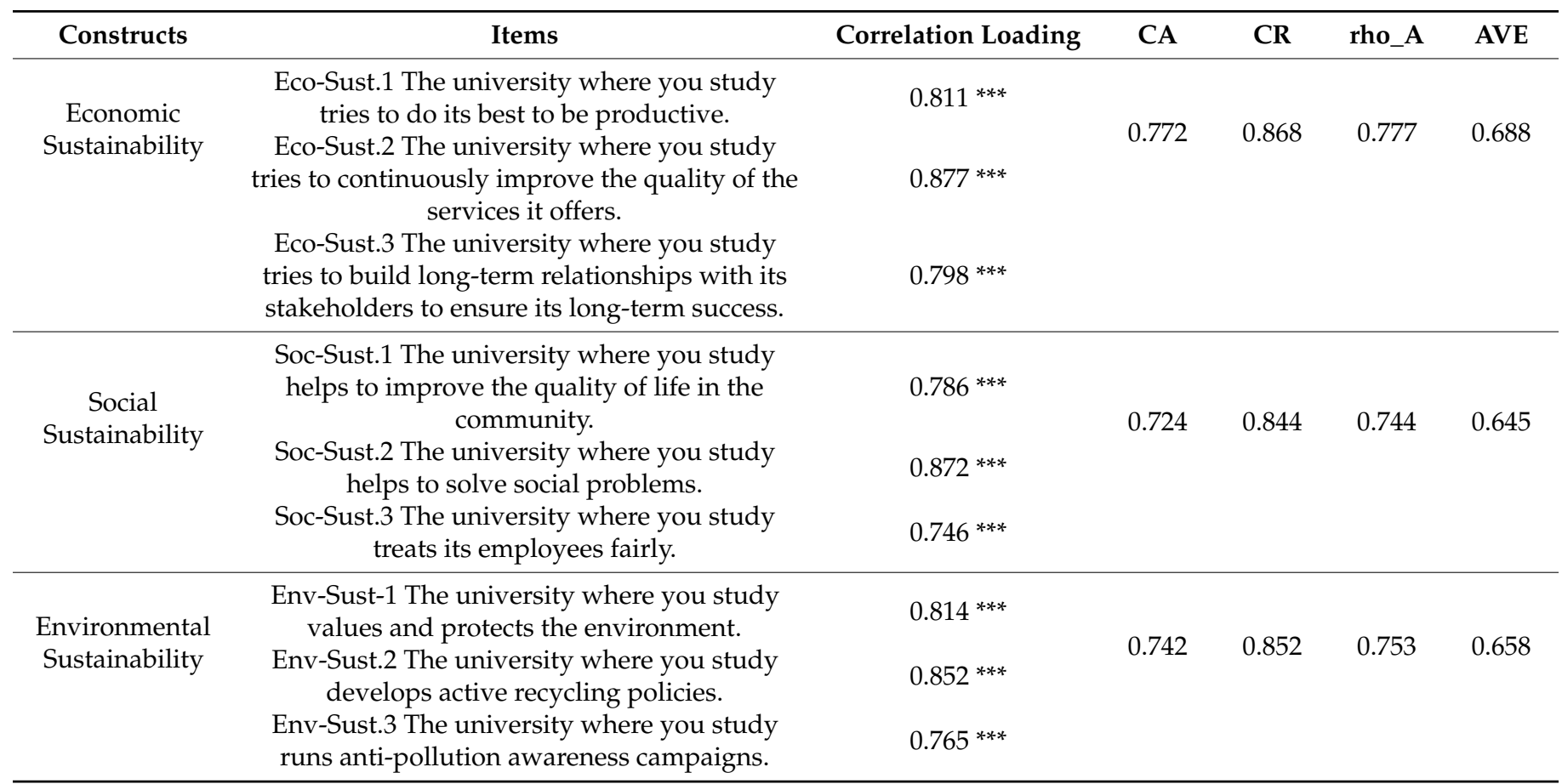

Note: $\mathrm{CA}=$ Cronbach's alpha; $\mathrm{CR}=$ composite reliability; rho_A = Dijkstra-Henseler indicator; AVE = average variance extracted; $* * * p$-value $<0.001$. Source: The authors.

Table 4. Measurement of the first-order model (discriminant validity).

\begin{tabular}{ccccccc}
\hline Variables & Eco-Sust & Env-Sust & Soc-Sust & Eco-Sust & Env-Sust & Soc-Sust \\
\hline Eco-Sust & 0.829 & & & & & \\
Env-Sust & 0.390 & 0.811 & & 0.507 & & \\
Soc-Sust & 0.589 & 0.481 & 0.803 & 0.784 & 0.640 & \\
\hline
\end{tabular}

Note: Eco-Sust = economic sustainability; Env-Sust = environmental sustainability; Soc-Sust = social sustainability Source: The authors.

The analysis of individual item reliability was the first analysis to be carried out. This study focused on the loadings $(\lambda)$ of each item. Loadings indicate how much of the variance of an item is explained by its variable. The criterion applied in this study was previously proposed by Carmines and Zeller [65] who suggested that loadings should be greater than 0.708 . In our results, all analyzed items met this requirement.

Second, the reliability of the construct was tested. This analysis was carried out using three criteria: simple reliability, composite reliability $\left(\rho_{\mathrm{C}}\right)$, and Dijkstra-Henseler's rho $\left(\rho_{\mathrm{A}}\right)$. In simple reliability analyses, Cronbach's alpha must be equal to or higher than 0.70 [66]. We also computed composite reliability (CR) following Nunnally and Bernstein's [66] criteria. Finally, the Dijkstra-Henseler [67] criterion, better known as rho $\left(\rho_{\mathrm{A}}\right)$, was analyzed. This criterion is considered to be the only measurement analysis that provides true or consistent reliability. This criterion sets a cut-off threshold of 0.7 [67]. The results of all three analyses we performed confirmed that all variables included in the present study met the aforementioned three criteria.

Third, convergent validity was analyzed. This analysis allowed us to measure the amount of variance generated by the indicators of a variable, i.e., to see whether the indicators belonged to a single variable, and to confirm their one-dimensionality [68]. As proposed by Hair et al. [60], a cut-off index for this criterion is 0.5. Our results showed that all variables explained at least $50 \%$ of the variance of their indicators [69].

As a final step in the validation analysis of the measurement scale, we measured discriminant validity to establish whether each of the variables shared more variance with its indicators (AVE) than with the rest of the indicators included in our study. In this 
analysis, we used Fornell and Larcker's [70] analysis and the heterotrait-monotrait (HTMT) ratio of correlations [71]. As can be seen in Table 3, the variables and items of the study met the requirements of discriminant validity. Specifically, in the Fornell and Larcker [70] analysis, the AVE were higher than the correlations between variables; furthermore, in the HTMT, the ratio relationships were below $0.9[60,72]$.

\subsection{Structural Model Analysis}

Once the proposed measurement scale was validated, we considered possible problems of multicollinearity [60]. To this end, we considered the structural VIF, which must be below 5 [69]. In this study, all VIF indicators were below 1.5, suggesting that there was no multicollinearity in the model.

Another important input to the study is the model fit index, which measures the difference between the observed correlation matrix and the correlation matrix implied by the model [73]. According to Williams, Vandenberg, and Edwards [74], a model has a good fit when SRMR is below 0.10. In the present study, the SRMR was set at 0.08 .

Testing the hypotheses entailed the following two steps: First, we tested hypotheses H.1a/H.2a/H.3a on the relationships among environmental sustainability, economic sustainability, and social sustainability. Second, a multi-group analysis was carried out to test the remaining three hypotheses $\mathrm{H} .1 \mathrm{~b} / \mathrm{H} .2 \mathrm{~b} / \mathrm{H} .3 \mathrm{~b}$ on the possible moderating effect of gender on the relationships among the different types of sustainability.

To test hypotheses H.1a/H.2a/H.3, a bootstrapping of 10,000 samples was carried out. The results showed that all three hypotheses were supported, as direct and positive relationships were found (see Table 4). Economic sustainability was found to directly and positively influence environmental sustainability (path coefficient of 0.163 ). Economic sustainability was found to directly and positively influence social sustainability (path coefficient of 0.589 ). Finally, social sustainability was found to directly and positively influence environmental sustainability (path coefficient of 0.385 ).

We also analyzed the coefficient of determination $\left(\mathrm{R}^{2}\right.$ values), effect size $\left(\mathrm{f}^{2}\right)$ and the predictive relevance of the model $\left(\mathrm{Q}^{2}\right)$. The results of these analyses are summarized in Table 5. In the study of the variance explained $\left(\mathrm{R}^{2}\right)$, following the Chin (1998) criterion, environmental sustainability had a low (but close to moderate) $\mathrm{R}^{2}$ of $25 \%$; for social sustainability, $\mathrm{R}^{2}$ was medium or moderate (35\%).

Table 5. Comparison of hypotheses.

\begin{tabular}{|c|c|c|c|}
\hline Hypotheses & Path Coeffc $(\mathcal{B})$ & Statistics T (B/STDEV) & $\mathbf{f}^{2}$ \\
\hline H1a. Eco-Sust $\rightarrow$ Env-Sust ${ }^{* *}$ & 0.163 & 2.465 & 0.023 \\
\hline H2a. Eco-Sust $\rightarrow$ Soc-Sust $* * *$ & 0.589 & 15.048 & 0.531 \\
\hline H3a. Soc-Sust $\rightarrow$ Env-Sust $* * *$ & 0.385 & 6.259 & 0.129 \\
\hline
\end{tabular}

$\mathrm{R}^{2}$ : Env-Sust $=0.249 ;$ Soc-Sust $=0.347 ; \mathrm{R}^{2}$ tight: Env-Sust = 0.245; Soc-Sust $=0.345 ; \mathrm{Q}^{2}$ : Env-Sust = 0.154; Soc-Sust $=0.219$. Note: Eco-Sust $=$ economic sustainability; Env-Sust $=$ environmental sustainability; Sos-Sust $=$ social sustainability; ${ }^{* *} p$-value $<0.01 ;{ }^{* * *} p$-value $<0.001$. Source: The authors.

Regarding the effect size $\left(\mathrm{f}^{2}\right)$, the relationship between economic sustainability and social sustainability had a small effect on environmental sustainability $\left(\mathrm{f}^{2}=0.023\right.$ and 0.129 , respectively), while economic sustainability had a large effect on social sustainability $\left(\mathrm{f}^{2}=0.531\right)$.

Finally, we ran a relevance analysis that allowed us to evaluate the predictive accuracy of the model [75]. The results of this analysis indicated that the model had predictive validity. According to Hair et al.'s [60] criteria, the effect of environmental sustainability and social sustainability was small.

\subsection{Multi-Group Moderating Effect}

Next, to test the remaining hypotheses $\mathrm{H} 1 \mathrm{~b} / \mathrm{H} 2 \mathrm{~b} / \mathrm{H} 3$ that concerned the mediating role of gender on the relationships among the three types of sustainability, we proceeded 
to perform a multi-group analysis. To this end, we first ran measurement invariance tests of variables (MICOM) [76]. MICOM is a prerequisite for multi-group analysis [69,77,78].

The results of the MICOM analysis are summarized in Table 6. As can be seen in the results, the sample had complete invariance for economic sustainability and environmental sustainability. However, in the case of social sustainability, partial invariance was obtained. These results allowed us to carry out a multi-group analysis to study whether there were significant differences according to gender.

Table 6. Results of Invariance Measurement Testing Using Permutation (MICOM).

\begin{tabular}{|c|c|c|c|c|c|c|c|c|c|c|c|}
\hline \multirow{2}{*}{ Constructs } & \multirow{2}{*}{$\begin{array}{c}\text { Configural } \\
\text { Invari- } \\
\text { ance }\end{array}$} & \multicolumn{2}{|c|}{$\begin{array}{l}\text { Compositional } \\
\text { Invarience }\end{array}$} & \multirow{2}{*}{$\begin{array}{l}\text { Partial Mea- } \\
\text { surement } \\
\text { Invariance } \\
\text { Established }\end{array}$} & \multicolumn{3}{|c|}{ Equal Mean Assessment } & \multicolumn{3}{|c|}{ Equal Variance Assessment } & \multirow{2}{*}{$\begin{array}{l}\text { Full Mea- } \\
\text { surement } \\
\text { Invariance } \\
\text { Established }\end{array}$} \\
\hline & & $C=1$ & $\begin{array}{c}\text { Confidence } \\
\text { Interval }\end{array}$ & & Differences & $\begin{array}{l}\text { Confidence } \\
\text { Interval }\end{array}$ & Equal & Differences & $\begin{array}{l}\text { Confidence } \\
\text { Interval }\end{array}$ & Equal & \\
\hline Eco-Sust & YES & 1.000 & $(0.995 / 1.000)$ & YES & 0.118 & $(-0.216 / 0.221)$ & YES & 0.236 & $(-0.309 / 0.287)$ & YES & YES \\
\hline Env-Sust & YES & 0.994 & $(0.989 / 1.000)$ & YES & -0.130 & $(-0.207 / 0.224)$ & YES & 0.331 & $(-0.353 / 0.326)$ & YES & YES \\
\hline Soc-Sust & YES & 0.996 & $(0.993 / 1.000)$ & YES & 0.015 & $(-0.214 / 0.221)$ & YES & 0.340 & $(-0.331 / 0.304)$ & NO & NO \\
\hline
\end{tabular}

Note: Eco-Sust = economic sustainability; Env-Sust = enviromental sustainability; Sos-Sust = social sustainability. Source: The authors.

Next, we performed a multi-group analysis using the permutation study, which is currently the most widely applied technique [69]. The results are reported in Table 7.

Table 7. Multi-group hypothesis testing.

\begin{tabular}{|c|c|c|c|c|c|c|}
\hline \multirow[b]{2}{*}{ Relationship } & \multicolumn{3}{|c|}{ Path Coefficient } & \multirow{2}{*}{$\begin{array}{c}\text { Confidence Interval } \\
(2.5 \% ; 97.5 \%)\end{array}$} & \multirow{2}{*}{$p$-Value } & \multirow[b]{2}{*}{ Supported } \\
\hline & Men & Women & Difference & & & \\
\hline H1b. Eco-Sust $\rightarrow$ Env-Sust & 0.107 & 0.219 & -0.113 & $(-0.287 ; 0.286)$ & 0.441 & $\mathrm{NO}$ \\
\hline H2b. Eco-Sust $\rightarrow$ Sos-Sust & 0.642 & 0.564 & 0.078 & $(-0.170 ; 0,167)$ & 0.368 & NO \\
\hline H3b. Soc-Sust $\rightarrow$ Env-Sust & 0.555 & 0.250 & 0.305 & $(-0.272 ; 0.271)$ & 0.026 & YES \\
\hline
\end{tabular}

Source: The authors.

As can be seen in Table 6, for hypotheses H1b and H2b, there was no moderating effect according to gender, while for $\mathrm{H} 3 \mathrm{~b}$, a moderate effect of gender was observed. Therefore, hypothesis $\mathrm{H} 3 \mathrm{~b}$ was substantiated by the results, while hypotheses $\mathrm{H} 1 \mathrm{~b}$ and $\mathrm{H} 2 \mathrm{~b}$ had to be rejected.

Therefore, it can be said that the gender moderation is higher in the male group than in the female group when analyzing the relationship between social and environmental sustainability. This implies that knowing the population by gender is important when it comes to implementing sustainability policies. At the organisational level, social sustainability varies in its relationship to environmental sustainability according to the perspective of stakeholders. This is why companies must take the gender variable into account when promoting or implementing sustainability. Figure $2 \mathrm{a}, \mathrm{b}$ shows results of assessment of model in men and women. 


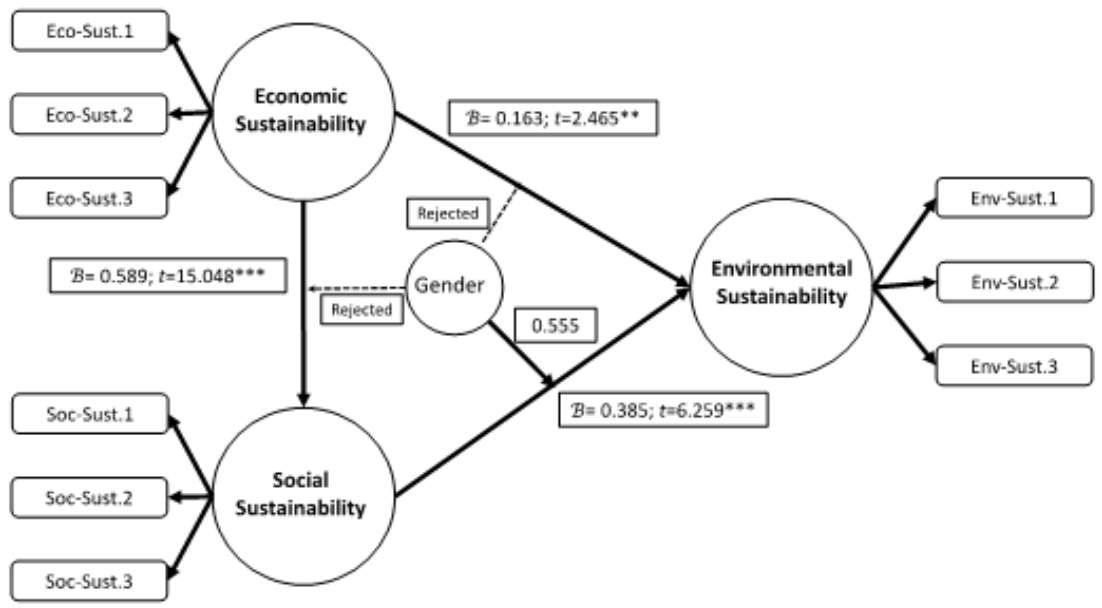

(a)

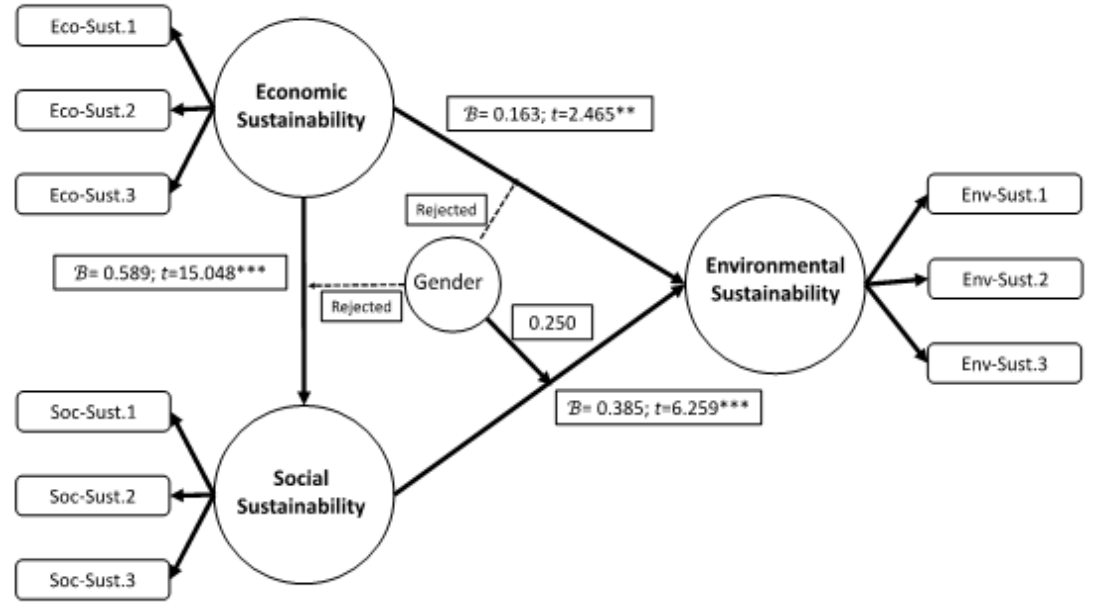

(b)

Figure 2. Final model. Results of assessment of model in men (a) and women (b). ${ }^{* *} p$-value $<0.01$; *** $p$-value $<0.001$.

\section{Conclusions}

In this study, we used a PLS model to explore the relationships among environmental, social, and economic types of sustainability, as well as whether (and if so, how) gender moderates these relationships.

To this end, survey responses of a total of 411 university students were analyzed. The results confirmed positive relationships among the three dimensions of sustainability. However, the moderating role of gender was confirmed only for the relationship between social and environmental sustainability.

Taken together, the present results demonstrate the links between different types of sustainability, such as the relationship between social sustainability, understood as the social organizational system that reduces poverty, and environmental sustainability, which is focused on the biological processes linked to productivity and the maintenance of ecosystems.

Furthermore, our finding concerning the moderating role of gender for decision making regarding sustainability provides important insights for the tourism sector. For instance, these results can be used by tourism companies and organizations to develop strategies and specific communication protocols that would take into account gender as a variable that can influence customers' perception and attitudes towards social and environmental sustainability. 
From the theoretical perspective, the variables operationalized in our model may be used to develop new research hypotheses to expand knowledge concerning how gender influences sustainability.

\subsection{Theoretical Implications}

Taking into account the literature analyzed on this topic, we can say that this study contributes to the academic literature as, to best our knowledge, there are few studies that examine the relationship between gender and the three dimensions of sustainability. Furthermore, the variables operationalized in the model may be used to develop new research hypotheses to expand knowledge [79] concerning how gender influences sustainability. In addition to this, our results contribute to the existing literature on the relationships between the three dimensions of sustainability.

\subsection{Practical Implications}

From the applied perspective, the present study contributes not only to previous research on sustainability as a whole, but also to policies that can be linked to sustainability strategies in the business ecosystem or to institutions such as the United Nations, the World Health Organization, or the World Tourism Organization, all of which promote the development of policies to protect the tourism ecosystem in the face of the massive increase of tourists around the world. In addition to this, this study has a practical implication for companies as sustainability is an important issue and based on the results companies should not use different sustainability strategies differentiating users by gender.

\section{Limitations}

The limitations of the present study include that it involved a relatively small number of respondents. In addition, only university students were surveyed. This suggests that, in future research, it would be necessary to conduct larger-scale studies that would include different population cohorts.

Despite these limitations, the present study underscores the importance of studying the economic, social, and environmental dimensions of sustainability, that encompass the concept of sustainability, with respect to emerging trends and consumption patterns that may modify the natural ecosystem.

Author Contributions: Conceptualization, V.G., J.-G.M.-N. and J.R.S.; methodology, J.-G.M.-N.; software, J.-G.M.-N.; validation V.G., J.R.S.; formal analysis, V.G., J.R.S.; investigation, V.G., J.-G.M.-N. and J.R.S.; resources, V.G., J.-G.M.-N. and J.R.S.; data curation, J.-G.M.-N.; writing-original draft preparation, V.G., J.-G.M.-N. and J.R.S.; writing-review and editing, V.G., J.-G.M.-N. and J.R.S.; visualization, V.G., J.-G.M.-N. and J.R.S. All authors have read and agreed to the published version of the manuscript.

Funding: This research received no external funding.

Institutional Review Board Statement: Not applicable.

Informed Consent Statement: Not applicable.

Conflicts of Interest: The authors declare no conflict of interest.

\section{References}

1. Basiago, A.D. Economic, Social, and Environmental Sustainability in Development Theory and Urban Planning Practice. Sustainability 1998, 19, 145-161.

2. Strezov, V.; Evans, A.; Evans, T.J. Assessment of the Economic, Social and Environmental Dimensions of the Indicators for Sustainable Development. Sustain. Dev. 2017, 25, 242-253. [CrossRef]

3. Goodland, R. No The Urgent Need for Ecosystem Integrity and Ethics to Support Environmental Sustainability. Glob. Bioeth. 1998, 11, 29-46. [CrossRef]

4. Hák, T.; Janouškova, S.; Moldan, B.; Dahl, A.L. Closing the Sustainability Gap: 30 Years after "Our Common Future”, Society Lacks Meaningful Stories and Relevant Indicators to Make the Right Decisions and Build Public Support. Ecol. Indic. 2018, 87, 193-195. [CrossRef] 
5. Purvis, B.; Mao, Y.; Robinson, D. Three Pillars of Sustainability: In Search of Conceptual Origins. Sustain. Sci. $2019,14,681-695$. [CrossRef]

6. Eizenberg, E.; Jabareen, Y. Social Sustainability: A New Conceptual Framework. Sustainability 2017, 9, 68. [CrossRef]

7. Saura, J.R.; Ribeiro-Soriano, D.; Palacios-Marqués, D. Using data mining techniques to explore security issues in smart living environments in Twitter. Comput. Commun. 2021, 179, 285-295. [CrossRef]

8. Olsson, D.; Gericke, N. The Effect of Gender on Students' Sustainability Consciousness: A Nationwide Swedish Study. J. Environ. Educ. 2017, 48, 357-370. [CrossRef]

9. Saura, J.R.; Ribeiro-Soriano, D.; Palacios-Marqués, D. Setting B2B Digital Marketing in Artificial Intelligence-based CRMs: A review and directions for future research. Ind. Mark. Manag. 2021, 98, 161-178. [CrossRef]

10. Brundtland, G.H.; Khalid, M.; Agnelli, S.; Al-Athel, S.; Chidzero, B. Our Common Future; United Nations: New York, NY, USA, 1987.

11. Christen, M.; Schmidt, S. A Formal Framework for Conceptions of Sustainability-A Theoretical Contribution to the Discourse in Sustainable Development. Sustain. Dev. 2012, 20, 400-410. [CrossRef]

12. Hodgson, G. Reimagining Growth: Towards a Renewal of Development Theory. In Institutions and Economic Development: Constraining, Enabling and Reconstituting; Dymski, G., Paula, S.D., Eds.; Zed Books: London, UK, 2005.

13. Herbohn, K.; Walker, J.; Loo, H.Y.M. Corporate Social Responsibility: The Link between Sustainability Disclosure and Sustainability Performance. Abacus 2014, 50, 422-459. [CrossRef]

14. Manzhynski, S.; Figge, F. Coopetition for Sustainability: Between Organizational Benefit and Societal Good. Bus. Strateg. Environ. 2020, 29, 827-837. [CrossRef]

15. Ortiz-de-Mandojana, N.; Bansal, P. The Long-term Benefits of Organizational Resilience through Sustainable Business Practices. Strateg. Manag. J. 2016, 37, 1615-1631. [CrossRef]

16. Adams, R.; Martin, S.; Boom, K. University Culture and Sustainability: Designing and Implementing an Enabling Frame-Work. J. Clean. Prod. 2018, 171, 434-445. [CrossRef]

17. Leal Filho, W.; Shiel, C.; Paço, A.; Mifsud, M.; Ávila, L.V.; Brandli, L.L.; Caeiro, S. Sustainable Development Goals and Sustainability Teaching at Universities: Falling behind or Getting Ahead of the Pack? J. Clean. Prod. 2019, 232, 285-294. [CrossRef]

18. Pappas, E. A New Systems Approach to Sustainability: University Responsibility for Teaching Sustainability in Contexts. J. Sustain. Educ. 2012, 3, 3-18.

19. Atanda, J.O. Developing a Social Sustainability Assessment Framework. Sustain. Cities Soc. 2019, 44, 237-252. [CrossRef]

20. Dempsey, N.; Bramley, G.; Power, S.; Brown, C. The Social Dimension of Sustainable Development: Defining Urban Social Sustainability. Sustain. Dev. 2011, 19, 289-300. [CrossRef]

21. Opp, S.M. The Forgotten Pillar: A Definition for the Measurement of Social Sustainability in American Cities. Local Environ. 2017, 22, 286-305. [CrossRef]

22. Rogge, N.; Theesfeld, I.; Strassner, C. Social sustainability through social interaction-A national survey on community gardens in Germany. Sustainability 2018, 10, 1085. [CrossRef]

23. Alkaher, I.; Gan, D. The Role of School Partnerships in Promoting Education for Sustainability and Social Capital. J. Environ. Educ. 2020, 51, 416-433. [CrossRef]

24. Ballet, J.; Bazin, D.; Mahieu, F.R. A Policy Framework for Social Sustainability: Social Cohesion, Equity and Safety. Sustain. Dev. 2020, 28, 1388-1394. [CrossRef]

25. Thabiso, M.; Awuzie, B. Mainstreaming Social Sustainability into Infrastructure Delivery Systems: Are There Any Benefits? A Stakeholders' Perspective. In Proceedings of the 11th Built Environment Conference, Durban, South Africa, 6-8 August 2017.

26. Cadil, J.; Mirosnik, K.; Petkovova, L.; Mirvald, M. Public Support of Private R\&D-Effects on Economic Sustainability. Sustainability 2018, 10, 4612 .

27. Doane, D.; MacGillivray, A. Economic Sustainability: The Business of Staying in Business; The SIGMA Project: Milano, Italy, 2001; Volume 34, pp. 1-52.

28. Pena-Cerezo, M.A.; Artaraz-Minon, M.; Tejedor-Nunez, J. Analysis of the Consciousness of University Undergraduates for Sustainable Consumption. Sustainability 2019, 11, 4597. [CrossRef]

29. Moldan, B.; Janoušková, S.; Hák, T. How to Understand and Measure Environmental Sustainability: Indicators and Targets. Ecol. Indic. 2012, 17, 4-13. [CrossRef]

30. Conrad, Z.; Niles, M.T.; Neher, D.A.; Roy, E.D.; Tichenor, N.E.; Jahns, L. Relationship between Food Waste, Diet Quality and Environmental Sustainability. PLoS ONE 2018, 13, e0195405. [CrossRef] [PubMed]

31. Kasayanond, A.; Umam, R.; Jermsittiparsert, K. Environmental Sustainability and Its Growth in Malaysia by Elaborating the Green Economy and Environmental Efficiency. Int. J. Energy Econ. Policy 2019, 9, 465. [CrossRef]

32. Ossebaard, H.C.; Lachman, P. Climate Change, Environmental Sustainability and Health Care Quality. Int. J. Qual. Health Care 2021, 33, mzaa036. [CrossRef]

33. Rehman, A.; Ma, H.; Ahmad, M.; Irfan, M.; Traore, O.; Chandio, A.A. Towards Environmental Sustainability: Devolving the Influence of Carbon Dioxide Emission to Population Growth, Climate Change, Forestry, Livestock and Crops Production in Pakistan. Ecol. Indic. 2021, 125, 107460. [CrossRef]

34. Howes, M.; Wortley, L.; Potts, R.; Dedekorkut-Howes, A.; Serrao-Neumann, S.; Davidson, J.; Smith, T.; Nunn, P. Environmental Sustainability: A Case of Policy Implementation Failure? Sustainability 2017, 9, 165. [CrossRef] 
35. Yukselturk, E.; Bulut, S. Gender Differences in Self-Regulated Online Learning Environment. J. Educ. Technol. Soc. 2009, 12, 12-22.

36. Fisher, P.J.; Yao, R. Gender Differences in Financial Risk Tolerance. J. Econ. Psychol. 2017, 61, 191-202. [CrossRef]

37. Saura, J.R.; Palacios-Marqués, D.; Iturricha-Fernández, A. Ethical Design in Social Media: Assessing the main performance measurements of user online behavior modification. J. Bus. Res. 2021, 129, 271-281. [CrossRef]

38. Ausín, B.; González-Sanguino, C.; Castellanos, M.Á.; Muñoz, M. Gender-Related Differences in the Psychological Impact of Confinement as a Consequence of COVID-19 in Spain. J. Gend. Stud. 2021, 30, 29-38. [CrossRef]

39. Powell, M.; Ansic, D. Gender Differences in Risk Behaviour in Financial Decision-Making: An Experimental Analysis. J. Econ. Psychol. 1997, 18, 605-628. [CrossRef]

40. Brooks, C.; Sangiorgi, I.; Hillenbrand, C.; Money, K. Experience Wears the Trousers: Exploring Gender and Attitude to Financial Risk. J. Econ. Behav. Organ. 2019, 163, 483-515. [CrossRef]

41. Jones III, R.J.; Reilly, T.M.; Cox, M.Z.; Cole, B.M. Gender Makes a Difference: Investigating Consumer Purchasing Behavior and Attitudes toward Corporate Social Responsibility Policies. Corp. Soc. Responsib. Environ. Manag. 2017, 24, 133-144. [CrossRef]

42. Richard, M.O.; Chebat, J.C.; Yang, Z.; Putrevu, S. A Proposed Model of Online Consumer Behavior: Assessing the Role of Gender. J. Bus. Res. 2010, 63, 926-934. [CrossRef]

43. Kim, M.J.; Lee, C.K.; Chung, N. Investigating the Role of Trust and Gender in Online Tourism Shopping in South Korea. J. Hosp. Tour. Res. 2013, 37, 377-401. [CrossRef]

44. Galbreath, J. Are There Gender-Related Influences on Corporate Sustainability? A Study of Women on Boards of Directors. J. Manag. Organ. 2011, 17, 17-38. [CrossRef]

45. Brown, B.J.; Hanson, M.E.; Liverman, D.M.; Merideth, R.W. Global Sustainability: Toward Definition. Environ. Manag. 1987, 11, 713-719. [CrossRef]

46. Sulewski, P.; Kłoczko-Gajewska, A.; Sroka, W. Relations between Agri-Environmental, Economic and Social Dimensions of Farms' Sustainability. Sustainability 2018, 10, 4629. [CrossRef]

47. Leach, M. (Ed.) Gender Equality and Sustainable Development; Routledge: Sussex, UK, 2015.

48. Glass, C.; Cook, A.; Ingersoll, A.R. Do Women Leaders Promote Sustainability? Analyzing the Effect of Corporate Governance Composition on Environmental Performance. Bus. Strateg. Environ. 2017, 25, 495-511. [CrossRef]

49. Sarvari, R.D. Elkington Concept for the Inclusion and Sustainability of the National Economy. Ph.D. Thesis, Polotsk State University, Navapolatsk, Belarus, 2020.

50. Schaltegger, S.; Wagner, M. (Eds.) . Managing the Business Case for Sustainability: The Integration of Social, Environmental and Economic Performance; Routledge: New York, NY, USA, 2017.

51. Lynott, P.P.; McCandless, N.J. The Impact of Age vs. Life Experience on the Gender Role Attitudes of Women in Different Cohorts. J. Women Aging 2000, 12, 5-21. [CrossRef] [PubMed]

52. Littig, B.; Griessler, E. Social Sustainability: A Catchword between Political Pragmatism and Social Theory. Int. J. Sustain. Dev. 2005, 8, 65-79. [CrossRef]

53. Cace, S.; Arpinte, D.; Cace, C.; Cojocaru, S. The Social Economy. An Integrating Approach. Transylv. Rev. Adm. Sci. 2011, 33E, 49-66.

54. Morris, M.G.; Venkatesh, V. Age Differences in Technology Adoption Decisions: Implications for a Changing Work Force. Pers. Psychol. 2000, 53, 375-403. [CrossRef]

55. Murphy, K. The Social Pillar of Sustainable Development: A Literature Review and Framework for Policy Analysis. Sustain. Sci. Pract. Policy 2012, 8, 15-29. [CrossRef]

56. Ravindran, T.; Yeow Kuan, A.C.; Hoe Lian, D.G. Antecedents and Effects of Social Network Fatigue. J. Assoc. Inf. Sci. Technol. 2014, 65, 2306-2320. [CrossRef]

57. United Nations. The Sustainable Development Agenda 2015-2030; United Nations: San Francisco, CA, USA, 2015.

58. Fernández-Fernández, M.; Martínez-Navalón, J.G.; Gelashvili, V. Sustainability and Online Classes at the University in the Times of COVID-19: Has It Served Us as a Starting Point for a New Kind of Teaching? Rev. Espac. 2021, 42, 127-144.

59. Hallak, R.; Assaker, G.; O'Connor, P.; Lee, G. Firm Performance in the Upscale Restaurant Sector: The Effects of Resilience, Creative Self-Efficacy, Innovation and Industry Experience. J. Retail. Consum. Serv. 2018, 40, 229-240. [CrossRef]

60. Hair, J.F.; Risher, J.J.; Sarstedt, M.; Ringle, C.M. When to Use and How to Report the Results of PLS-SEM. Eur. Bus. Rev. 2019, 31, 2-24. [CrossRef]

61. Del-Castillo-Feito, C.; Blanco-González, A.; González-Vázquez, E. The Relationship between Image and Reputation in the Spanish Public University. Eur. Res. Manag. Bus. Econ. 2019, 25, 87-92. [CrossRef]

62. Rodríguez, G.C.; Román, C.P.; Zúñiga-Vicente, J.Á. The Relationship between Identification and Loyalty in a Public University: Are There Differences between (the Perceptions) Professors and Graduates? Eur. Res. Manag. Bus. Econ. 2019, 25, 122-128. [CrossRef]

63. Ministry of Science, Innovation and Universities. Data and Figures of the Spanish University System. Publication $2018-2019$. Available online: https:/ / www.ciencia.gob.es/stfls/MICINN/Universidades/Ficheros/Estadisticas/datos-y-cifras-sue-2018 -19.pdf (accessed on 12 May 2021).

64. Del-Castillo-Feito, C.; Cachón-Rodríguez, G.; Paz-Gil, I. Political Disaffection, Sociodemographic, and Psychographic Variables as State Legitimacy Determinants in the European Union. Am. Behav. Sci. 2020, 17, 0002764220981116. [CrossRef]

65. Carmines, E.; Zeller, R. Reliability and Validity Assessment; Sage Publishing: Thousand Oak, CA, USA, 1979. 
66. Nunnally, J.C.; Bernstein, I.H. Psychometric Theory, 3rd ed.; MCGraw-Hil: New York, NY, USA, 1994.

67. Dijkstra, T.K.; Henseler, J. Consistent Partial Least Squares Path Modeling. MIS Q. 2015, 39, 297-316. [CrossRef]

68. Henseler, J.; Ringle, C.M.; Sinkovics, R.R. The Use of Partial Least Squares Path Modeling in International Marketing. Adv. Int. Mark. 2009, 20, 277-320.

69. Hair, J.F.; Sarstedt, M.; Ringle, C.M.; Gudergan, S.P. Advance Issues in Partial Least Squares Structural Equation Modeling; SAGE Publications: Los Angele, CA, USA, 2018.

70. Fornell, C.; Larcker, D.F. Structure Equation Models: LISREL and PLS Applied to Customer Exist-Voice Theory. J. Mark. Res. 1981, 18, 39-50. [CrossRef]

71. Henseler, J.; Ringle, C.M.; Sarstedt, M. A New Criterion for Assessing Discriminant Validity in Variance-Based Structural Equation Modeling. J. Acad. Mark. Sci. 2015, 43, 115-135. [CrossRef]

72. Kline, P. Oaxaca-Blinder as a Reweighting Estimator. Am. Econ. Rev. 2011, 101, 532-537. [CrossRef]

73. Henseler, J. Using Variance-Based Structural Equation Modeling for Empirical Advertising Research at the Interface of Design and Behavioral Research. J. Advert. 2017, 46, 178-192. [CrossRef]

74. Williams, L.; Vandenberg, R.J.; Edwards, R.J. Structural Equation Modeling in Management Research: A Guide for Improved Analysis. Acad. Manag. 2009, 3, 543-604. [CrossRef]

75. Geisser, S. The Predictive Sample Reuse Method with Applications. J. Am. Stat. Assoc. 1975, 70, 320-328. [CrossRef]

76. Hair, J.F.; Hult, G.T.M.; Ringle, C.; Sarstedt, M. A Primer on Partial Least Squares Structural Equation Modeling (PLS-SEM); SAGE: Thousand Oaks, CA, USA, 2014.

77. Henseler, J.; Ringle, C.M.; Sarstedt, M. Testing Measurement Invariance of Composites Using Partial Least Squares. Int. Mark. Rev. 2016, 33, 405-431. [CrossRef]

78. Rasoolimanesh, S.M.; Roldán, J.L.; Jaafar, M.; Ramayah, T. Factors Influencing Residents' Perceptions toward Tourism Defelopment: Differences across Rural and Urban World Heritage Sites. J. Travel Res. 2017, 56, 760-775. [CrossRef]

79. Saura, J.R.; Palos-Sanchez, P.; Blanco-González, A. The importance of information service offerings of collaborative CRMs on decision-making in B2B marketing. J. Bus. Ind. Mark. 2019, 35, 470-482. [CrossRef] 